\title{
Samuel Klumpenhouwer
}

ORCID: https://orcid.org/0000-0003-2966-1470

University of Toronto, Canada

\section{Luigi Giussani and Catholic Historiography}

\begin{abstract}
This essay explores the difficulties of conducting historiographical research from a Catholic view point. It through the life and writings of Luigi Giussani, founder of the movement Communion and Liberation. Three main approaches to history will be explored: the rationalist approach, the Protestant approach, and finally the Orthodox-Catholic approach. The essay argues that only the third approach is sufficient to examine the historical claims about Jesus.
\end{abstract}

\section{Keywords}

Luigi Giussani, Communion and Liberation, Catholic Church, history, historiography, rationalism, Protestantism.

\section{Introduction to secular historiography}

There is an old story told about Ranke, the famous nineteenth century German historian. After Ranke had finished a certain book on the Reformation, a rather strenuous churchman came up to him and hailed him as a comrade. Ranke repelled the churchman's familiarity with him, saying "You are in the first place a Christian. I am in the first place a historian. There is a gulf between us."

What did Ranke mean by this? We are familiar with scholars of Ranke's type, scholars who may be religious, but strive to prevent that from effecting their

${ }^{1}$ J. D. Acton, A lecture on the study of history, London: Macmillan 1895, p. 50. 
work. This is part of the modernist vision, a vision of the disinterested historian presenting an unbiased, objective presentation of events. Ranke was aware that historians could never be completely objective. Yet he believed a historian should behave with that goal in mind, with being in the first place a historian. Despite the intense scrutiny this modernist scholarly vision has been subjected to in recent decades, in practice the academia still clings to this vision in one form or another.

This essay discusses an exemplar of the Christian historian, Luigi Giussani. He wrote many works, although none of them history books as normally conceived. One could classify them as theological anthropology, or perhaps even apologetics. But those designations do not do justice to Giussani's intent. The claim of this essay is that Giussani (ended up presenting) a distinct historiographic approach as a result of his reflections on humanity, the Incarnation and the Church. This historiographic approach, in short, is a relational one in the fullest sense of the word. Despite never having set out to do history, Giussani became a historian. He was a historian who was, to use Ranke's phrase, "in the first place a Christian".

\section{The life of Luigi Giussani}

Luigi Giussani was a Catholic priest born in 1922. He is well known within the Church, especially among the Italian community of believers. At his funeral Mass in 2005 eulogies were given by Pope John Paul II and Cardinal Ratzinger, soon to be Pope Benedict XVI. Here is what the Cardinal said about Giussani: "Already as a boy, along with other young men, he created a community called Studium Christi. Their program was to speak of nothing else but Christ, because everything else seemed to be a waste of time. Naturally, he was able to overcome the unilaterality, but he always kept the substance. Only Christ gives meaning to the whole of our life. Fr. Giussani always kept the eyes of his life and of his heart fixed on Christ. In this way, he understood that Christianity is not an intellectual system, a packet of dogmas, a moralism; Christianity is rather an encounter, a love story; it is an event."

${ }^{2}$ J. Ratzinger, In love with Christ. In an encounter, the road, in: Communion and Liberation, http://english.clonline.org/default.asp?id=605\&id_n=14571 (7.03.2018). 
Giussani lived out this event in Italy where he taught and worked with university students. He is best known for having started a group within the Catholic Church known as Communion and Liberation, a lay ecclesial movement that seeks to live the fullness of the faith in the activities of everyday life. Communion and Liberation continues today with groups scattered across the world. ${ }^{3}$

As already stated above, Giussani did not set out to be a historian. He began with an attentiveness to the human person, to life. According to Giussani life is nothing less than "hunger, thirst, and passion for an ultimate object, which looms over the horizon, and yet always lies beyond it. When this is recognized, man becomes a tireless searcher." ${ }^{\prime 4}$ In these words we already see a glimpse of the religious searching that characterized Giussani's historiographical approach. According to Giussani „Existence expresses itself, as ultimate ideal, in begging. The real protagonist of history is the beggar: Christ who begs for man's heart, and man's heart that begs for Christ." ${ }^{5}$ Giussani called this begging the religious sense. ${ }^{6}$

\section{The religious sense}

The religious sense as Giussani conceived it is distinct from the categorized varieties of religious experience that William James described. James discerned in the religious experience a type of human experience. For him, religious happiness was simply happiness. ${ }^{7}$ Giussani discerned in the human experience a religious sense. For him, every experience is an expression of one's religious sense.

What does Christianity and history have to do with the religious sense? Giussani saw that the origin of the Christian claim was that at a distinct moment in time and place there was a Jew walking around Palestine claiming himself to be the object of every person's desire. For Giussani, the question here was

${ }^{3}$ Cf. D. Rondoni (ed.), Communion and Liberation: A movement in the Church, trans. P. Stevenson and S. Scott, Montreal: McGill-Queen's University Press 2000.

${ }^{4}$ L. Giussani, The religious sense, trans. J. Zucchi, Montreal: McGill-Queen's University Press 1997, p. 51.

${ }^{5}$ L. Giussani, In the simplicity of my heart I have gladly given you everything, "Communion and Liberation”, http://english.clonline.org/default.asp?id=560\&id_n=14531 (7.03.2018).

${ }^{6}$ Cf. L. Giussani, The religious sense.

7 W. James, The varieties of religious experience, New York: Longmans 1917, p. 24. 
simple: did Christ's Incarnation happen or not? ${ }^{8}$ Giussani wanted to know how someone could assess with certainty whether this historical event occurred. Through facing this question Giussani's view of history began to take form.

According to Giussani there are three main ways that have been proposed to assess the historical event of the Incarnation: the rationalist approach, the Protestant approach, and the Orthodox-Catholic approach. ${ }^{9}$

\section{The rationalist approach}

The rationalist approach is essentially the historical-critical approach of Ranke, which remains dominant in the academia. It seeks to examine the past through documents and other material sources, and then classifies and evaluates these sources with various scientific categories. In other words, it strives by means of scientific research to overcome the remoteness of two thousand years of history. But this is the problem for Giussani. The message of the Incarnation is Emmanuel, God with us; God with us, in the present. The rationalist approach is only willing, a priori, to see Christ as a fact of the past. As Giussani says, this approach diminishes the content of the Christian message even before taking it into consideration. The rationalist wants to analyze the Incarnation as a historical fact, but it calls "historical" only what it has preconceived to be historical. It excludes the possibility that what history is, what a historical fact is, has been transformed by the Incarnation. In sum, for Giussani the rationalist approach taken by itself is insufficient and reductive. It is not open to the possibility of what the Incarnation might mean for history. The failures of this approach arise because the historian is not letting the object of investigation determine the method of investigation. ${ }^{10}$

Before moving on to the second approach that Giussani critiques, it is appropriate to examine what it would mean for one's conception of history if the Incarnation did occur. The Church is often said to have solidified in the West a linear view of history. ${ }^{11}$ This is true up to a point. There is eschaton as well

${ }^{8}$ L. Giussani, At the origin of the Christian claim, trans. J. Zucchi, Montreal: McGillQueen's University Press 1998, p. 30.

9 Cf. L. Giussani, Why the Church?, trans. J. Zucchi, Montreal: McGill-Queen's University Press 2001, p. 10-23.

${ }^{10}$ L. Giussani, Why the Church?, p. 11-17.

${ }^{11} \mathrm{P}$. Burke, Western historical thinking in a global perspective - 10 theses, in: Western historical thinking: an intercultural debate, ed. J. Rüsen, New York: Berghahn Books 2002, 
as creation. But it is a reduction to say that history, in the traditional Christian worldview, is a straight line from beginning to the end. For Giussani the Incarnation is a centering point, a transformation of the historical event. It is something he feels inadequate to describe and so he quotes from the late Mircea Eliade, historian of religion at the University of Chicago: "From the standpoint of the history of religions, Judaeo-Christianity presents us with the supreme hierophany: the transfiguration of the historical event into hierophany... This is more than just sacred time. For, to all appearances, Jesus of Nazareth is in no way distinguished from his contemporaries in Palestine... Jesus eats, digests suffers from thirst or from the heat, like any other Jew of Palestine. But, in reality, this "historical event" constituted by the existence of Jesus is a total theophany: what it presents is like an audacious effort to save the historical event in itself, by endowing it with the maximum of being...."12

The main thing to note here is that the historical event could not remain unchanged if the Incarnation actually happened. But the present moment was also given great importance. The Incarnation is not something that can be accessed only in the past. It is also an object of historical investigation that can be encountered in the present. This, therefore, is the problem with the rationalist attitude: it refuses to let the past be in the present.

\section{The Protestant approach}

The Protestant approach is one that seeks to address the question of Christ through inner enlightenment. Whereas the rationalist approach tried to bridge the two-thousand-year gap since the Incarnation through scientific research, the Protestant approach recognizes a transformation of the historical event. It seeks, however, through inner experience to "feel" the presence of Christ in the present. According to Giussani, it seeks to gain certainty through an interior, spiritual encounter. ${ }^{13}$ It looks to the Bible or spiritual writers for guidance, but in the end, it is an entirely subjective approach. This approach was not satisfying to Giussani. When the disciples encountered Christ, they encountered the God-man, who

p. 17-19.

12 As quoted in P. Burke, Western historical thinking in a global perspective - 10 theses, p. 49-50.

${ }^{13}$ L. Giussani, Why the Church?, p. 17-20. 
talked, ate, breathed. It was not simply an interior, spiritual encounter. Giussani wanted to know how someone can now, two thousand years after Jesus walked the Earth, encounter him with the same fullness as the apostles did. There must be no reductions to the encounter. Anything less than the disciple's encounter would mean this is not the answer to man's religious sense. ${ }^{14}$

\section{The Orthodox-Catholic approach}

Giussani found only the Orthodox-Catholic approach satisfying. According to him, this is the Christian tradition proper, and is an approach shared by both the Orthodox and Catholic churches. ${ }^{15}$ Here the presence of Christ is not a matter of the past or something that can only be experienced spiritually. It remains in the present in its fullness. For the Church is the continuation of Christ in history. ${ }^{16}$ The Church, the body of believers, is in a real way the body of Christ that the disciples encountered. ${ }^{17}$ In other words, the OrthodoxCatholic approach proposes a transformation of the historical event, such that someone today, can encounter Jesus in his fullness, as much as the disciples who walked with him in Palestine two thousand years ago. This encounter takes place in a special way in the Eucharist, which Catholics believe is the true presence of Christ. In the Eucharist there is another way to distinguish the Orthodox-Catholic attitude from both the Protestant and rationalist attitudes. Both the Protestant (generally speaking) and the rationalist deny the real presence of Christ in the Eucharist. Particularly for the Protestants, the issue has to do with the nature of memory, as they focus almost exclusively on the words of the Gospel: "Do this in memory of me..." ${ }^{18}$ But even for the rationalist, memory is also an important factor in historical research, whether one is analyzing the Incarnation or any other historical event. Consider the following reflections on memory by the historian Gabrielle Spiegel: "To the extent that memory 'reincarnates,' 'resurrects,' 're-cycles,' and makes the past 'reappear' and live again in the present, it cannot perform historically, since

\footnotetext{
14 L. Giussani, Why the Church?, p. 20.

15 L. Giussani, Why the Church?, p. 20.

${ }^{16}$ L. Giussani, Why the Church?, p. 21.

171 Corinthians 12:27.

18 Luke 22:19.
} 
it refuses to keep the past in the past, to draw the line, as it were, that is constitutive of the modern enterprise of historiography. History 're-presents' the dead; memory 're-members' the corpse in order revivify it. ${ }^{19}$ "

Spiegel is a reductionist, albeit an intelligent one. She refuses to let history be anything other than what the modern enterprise of historiography has preconceived it to be. Yet while she is a type of the rationalist earlier critiqued, she is pointing at an important aspect of memory. Memory is not simply a way of recalling the past to mind. Memory relives the past. But for her, this memory is defined against history. The two are opposed. Conversely, for Giussani memory preserves an original historical experience. ${ }^{20}$

The rationalist refuses to let the Eucharist have anything to do with the Incarnation. The past belongs to the past. History "represents" it, as Spiegel says, but it does only that. The Protestant is in part a rationalist, and says that the Eucharist is a representation of a past Incarnation. On the other hand, the Protestant is not entirely a rationalist and may also say that Christ is, in a special and unique way, spiritually present in the Eucharist. The remembrance of the Eucharist is thus not simply a representation. The dichotomy between history and memory is thus weakened. But still, the Incarnation cannot be experienced in the present entirely, body and spirit.

For Catholics, the dichotomy between memory and history is entirely broken. The Eucharist remembers the Incarnation in the sense that it continues the original experience in its entirety. In Spiegel's terms, one might then say that the past Incarnation is "reincarnated" in the present. But this is wrong. There is no "re- ". According to Giussani's terms, memory does not replicate the original experience, it preserves it. ${ }^{21}$ The Eucharist is not a multiplication of the Incarnation, but the continuance of it in history. In contradistinction to Spiegel, Giussani says: "The word memory, therefore, describes the history between the event at its origin and the encounter that makes the original event an unavoidable, indestructible, undeniable presence. The whole wealth of the beginning is within the present and it is in the present that man discovers the divinity of the origin. Memory is the history that runs from the origin up to the

19 G. Spiegel, Memory and history: liturgical time and historical time, "History and Theory" 41 (2002), p. 162.

20 L. Giussani, The religious sense, p. 84.

${ }^{21}$ L. Giussani, The religious sense, p. 84. 
present. The material content (thought, affection, work) of the word memory is also called Tradition."22

The significance of memory, in the fullest sense of the word, brings us back to the question Giussani is concerned with. How can someone, a day, a year, two thousand years after the Incarnation, know with certainty that this historical event happened, that the object of humanity's desire made itself known? Perhaps the title of one of Giussani's works says it best: The Journey to Truth is an Experience. ${ }^{23}$ It is an experience that Church remembers and offers as path to certainty. Certainty about the Incarnation comes about in the same way as for the apostles who walked with Christ. And so Giussani says: "I will be able to be certain about you to the extent that I pay more attention to your life, that is, that I share in your life. The signs leading to certainty become multiplied in the measure in which you pay attention to them. For example, in the Gospel, who was able to understand the need to trust that man? Not the crowd looking for a cure, but those who followed him and shared his life. This is to say that in order to know an object one must be tuned to it and this requires an active disposition which is developed through time and by living with the object." ${ }^{24}$

As previously said, the object determines the method. Giussani claims that the historian investigating the Incarnation is not faced with a distant event only, but with a person in the present. And how does one properly gain certainty about a person? Through experience - that is, through a relationship. This is what the Church remembers and offers.

\section{The Catholic historian}

Having completed this overview of Giussani's thought, it is appropriate to now take a step further back and clearly delineate the significance this has for historiography. The first thing to note is that Giussani grants an extreme privileging to historical inquiry. The religious sense, the greatest and only question a person

${ }^{22}$ L. Giussani, S. Alberto and J. Prades, Generating traces in the history of the world, trans. P. Stevenson, Montreal: McGill-Queen's University Press, 2010, p. 28.

${ }^{23}$ L. Giussani, The journey to truth is an experience, trans. J. Zucchi, Montreal: McGillQueen's University Press, 2006.

${ }^{24}$ L. Giussani, At the origin of the Christian claim, p. 41. 
can ask, is not a problem to be dealt with by philosophy or morals. It is instead addressed by a historical inquiry: "Did God really intervene in history?"25

The second thing to note is an extreme expansion of historical inquiry, both in terms of the object and method of investigation. Regarding the object of historical inquiry, we may recall Giussani's earlier quotation of Mircea Eliade: "But, in reality, this 'historical event' constituted by the existence of Jesus is a total theophany: what it presents is like an audacious effort to save the historical event in itself, by endowing it with the maximum of being...." ${ }^{26}$

This transformed historical event, "endowed with a maximum of being", signals the opening of the range of historical inquiry. Everything, not just the Incarnation, gains significance and becomes worthy of inquiry. According to Giussani, "Nothing is excluded from this positive embrace." ${ }^{27}$ Here, the history of the human person remains particularly important-as compared to the history of a forest or building, although these too are important. Yet in the history of the person the "purely banal act" is swept away. ${ }^{28}$ Every action, every historical event, assumes a dignity it would not otherwise have, and becomes worthy of historical inquiry.

With this in mind we may note, along with the expansion of the object and method of historical inquiry, a further expansion of the subject carrying out the inquiry. Particularly, but not solely, in the case of the Incarnation, those outside the academia may be better judges of its historical veracity. It is quite possible that their method of investigation is better suited than the methods used by professional historians. When this is true it is not a result of their fideism, which is also an unsuitable and reductive method of inquiry, but of their attentiveness to what is presented and a willingness to continually modify their method in light of new evidence. In other words, it is because of a commitment to a relationship with the object of investigation.

In Giussani's critique of the rationalist and Protestant approaches, his objection with them is not that they are incorrect, plain and simple, but rather that they are insufficient for the historical enquiry at hand. They are both reductive, and reduction of any kind is not accepted. Thus, anything that is not a negation in these approaches is valued. Of the rationalist and the Protestant he says:

\footnotetext{
${ }^{25}$ L. Giussani, At the origin of the Christian claim, p. 32.

${ }^{26}$ L. Giussani, At the origin of the Christian claim, p. 49-50.

${ }^{27}$ Luigi Giussani, et al., Generating traces in the history of the world, p. 116.

${ }^{28}$ Luigi Giussani, Why the Church?, p. 39.
} 
"I would like to stress that the first two attitudes we have studied do highlight certain values, and that these values are recognized and recovered in the [Orthodox-Catholic] attitude." ${ }^{29}$ For Giussani, nothing of value is to be disregarded, nothing of reduction is to be suffered. He showed the way of doing history, a way which encompasses everything of positive value.

\section{Bibliography}

Acton J. D., A lecture on the study of history, London: Macmillan 1895.

Burke P., Western historical thinking in a global perspective - 10 theses, in: Western historical thinking: an intercultural debate, 15-30. Ed. J. Rüsen, New York: Berghahn Books 2002.

James W., The varieties of religious experience, New York: Longmans 1917.

Giussani L., At the origin of the Christian claim, Trans. J. Zucchi, Montreal: McGillQueen's University Press 1998.

Giussani L., S. Alberto and J. Prades, Generating traces in the history of the world, Trans. P. Stevenson, Montreal: McGill-Queen's University Press 2010.

Giussani L., In the simplicity of my heart I have gladly given you everything, in: Communion and Liberation, http://english.clonline.org/default. asp?id=560\&id $\mathrm{n}=14531$ (7.03.2018).

Giussani L., The journey to truth is an experience, Trans. J. Zucchi, Montreal: McGillQueen's University Press 2006.

Giussani L., The religious sense, Trans. J. Zucchi, Montreal: McGill-Queen's University Press 1997.

Giussani L., Why the Church?, Trans. J. Zucchi, Montreal: McGill-Queen's University Press 2001.

Ratzinger J., In love with Christ. In an encounter, the road, in: Communion and Liberation, http://english.clonline.org/default.asp?id=605\&id_n =14571 (7.03.2018).

Rondoni D. (ed.), Communion and Liberation: a movement in the Church, Trans. P. Stevenson and S. Scott, Montreal: McGill-Queen's University Press 2000.

Spiegel G., Memory and history: liturgical time and historical time, "History and Theory" 41 (2002), pp149-162.

${ }^{29}$ Luigi Giussani, Why the Church?, p. 23. 